\title{
Analysis of Flavonoid Levels in Tin (Ficus carica Linn) Fruit
}

\author{
*Rahmasita, Siti Nuryanti \& Supriadi \\ Chemistry Education / FKIP - Tadulako University, Palu Indonesia 94119 \\ Received 11 December 2020, Revised 14 January 2021, Accepted 11 February 2021 \\ doi: 10.22487/j24775185.2021.v10.i1.pp32-35
}

\begin{abstract}
Tin fruit is an essential source of bioactive components such as phenol, benzaldehyde, and flavonoids due to the antioxidant properties. Analysis of flavonoid levels on Tin (Ficus carica Linn) fruit was carried out using Uv-Vis spectrophotometry. This study aimed to determine the total flavonoid levels found in Tin (Ficus carica Linn) fruit with a variety of samples of raw, half-ripe, and riped. Extraction of chemical content in Tin (Ficus carica Linn) was carried out by maceration method with ethanol 70\%. Total flavonoid levels of the extracts sample were determined through absorption measurements at a wavelength of $520 \mathrm{~nm}$ and $700 \mathrm{~nm}$. The results showed that total flavonoid levels in raw, half-ripe, and ripe fruits are $5.778 \times 10^{3}, 3.056 \times 10^{3}$, and $3.707 \times 10^{3} \mathrm{mg} / \mathrm{L}$, respectively, or equivalent to $17334 \times 10^{3}, 9.168 \times 10^{3}$, and $11.121 \times 10^{3} \mathrm{mg} / 100 \mathrm{~g}$, respectively.
\end{abstract}

Keywords: Flavonoids, tin (Ficus carica Linn), Uv-Vis Spectrophotometer

\section{Introduction}

Tin fruit usually grows in the Mediterranean climate, which is part of the subtropical climate. This climate is characterized by warm to hot and dry summers and mild and wet winters (Aytekin \& Caliskan, 2008).

Around 2004, Green Jordan and Purple Jordan figs began to enter Indonesia. June 2006 was followed by the entry of the Negronne, Black Ischia, and Long Yellow types. The content of healthpromoting components in figs has been known for centuries, and humans have used this fruit as a source of traditional medicines (Ghazi et al., 2010). According to Crisosto et al. (2010), fresh figs could be used as medicine with their nutritional and phytochemical content. According to Sobir \& Mega (2011), this plant can thrive and bear fruit in the middle of the hot sun, even in the desert. Tin fruit is an essential source of bioactive components such as phenol, benzaldehyde, and flavonoids which have antioxidant properties and have shown an in vitro inhibitory effect on the proliferation of various cancer cells (Joseph \& Raj, 2011). According to Gupta \& Shaw (2015), flavonoids are involved in UV filtration, symbiotic fixation, and flower pigmentation.

Research on flavonoid levels in fruit has been carried out, such as research conducted by Aminah et al. (2016) on a determination of total flavonoid levels of ethanol extract of avocado rind (Persea americana mill.) by method UV-Vis Spectrophotometry and obtained flavonoid levels of
$4.0122 \mathrm{mgQE} / \mathrm{g}$ and research that has been conducted by Karmila (2018), determination of levels of flavonoids and vitamin $\mathrm{C}$ in forest onion bulbs (Eleutherine bulbosa (mill) urb) originating from the village of Matantimali, Sigi district and obtained levels of flavonoids of13.4058 $\times 10^{3}$ $\mathrm{mg} / 100 \mathrm{~g}$.

This paper is intended to describe the analysis of flavonoid levels in fig (Ficus carica Linn), which originated from the city of Palu, Central Sulawesi.

\section{Methods}

The tools used in this research are dropper pipette, measuring cup, beaker, Erlenmeyer, test tube, stirring rod, funnel, digital balance, cuvette, test tube rack, shaker, rotary evaporator, spatula, cutting board, knife, and UV-VIS spectrophotometer.

The materials used in this research are figs are raw, half-ripe, and ripe, tissue, aluminum foil, filter paper, distilled water, ethanol 70\% (Merck), $10 \% \mathrm{FeCl}_{3}$ solution(Merck), buffer solution $\mathrm{pH} 1$, and $\mathrm{pH} 4.5$ (Merck).

The sample used in this study was green Jordan varieties with 3 sample variations, namely raw figs, which were marked by green fruit skin, hard texture, fibrous flesh with a mixture of red and white and had sap, half-ripe figs marked with a yellowish-green skin color with black patches, a slightly mushy texture, yellow flesh, and a slightly sweet taste, and ripe figs were marked with yellow fruit skin with black spots, larger diameter, The

*Correspondence:

Rahmasita

e-mail: rahmasita@gmail.com

(c) 2021 the Author(s) retain the copyright of this article. This article is published under the terms of the Creative Commons Attribution License 4.0, which permits unrestricted non-commercial use, distribution, and reproduction in any medium, provided the original work is properly cited. 
texture is very soft, the flesh of the fruit is brownish red and has a sweet taste and a lot of water content. This sample was obtained in Tondo Village, Mantikulore District, Palu, Central Sulawesi.

\section{Sample Preparation}

Unripe, half-ripe, and ripe figs are separated from the flesh from the skin. The flesh of the figs that have been separated from the skin is then washed clean, then dried (aerated at room temperature), and cut into small pieces for further processing.

\section{Extraction Process}

Sample extraction in this study was carried out by researchers using a modification from Gustandy (2016), namely: 20 grams of raw, halfripe, and ripe samples of figs were weighed using a digital balance then put into Erlenmeyer and 200 $\mathrm{mL}$ of $70 \%$ ethanol solution was added. Erlenmeyer containing the sample solution was closed using aluminum foil, then shaken using a shaker at a speed of $240 \mathrm{rpm}$ for 30 minutes, and let stand for 24 hours. Remaceration 3 times, and each filtrate obtained was concentrated using a rotary evaporator until there was no more dripping liquid so that a concentrated fig extract was obtained. Then, the fig extract obtained was used for further analysis.

\section{Qualitative Analysis of Flavonoid Content}

The qualitative analysis of the flavonoid content in this study was carried out by researchers using a modification of the Harbone (1984) method, namely: $3 \mathrm{~mL}$ of raw, half-ripe, and ripe fig extract, each put into a test tube, then added five drops of $\mathrm{FeCl}_{3} 10 \%$. If a yellow, green, blue-green, orange to red color is formed in the solution, and then the positive sample contains flavonoids.

\section{Quantitative Analysis of Flavonoid Content}

Quantitative analysis of flavonoid content in this study was conducted using the modified differential $\mathrm{pH}$ method from Rezki et al. (2017), namely $3 \mathrm{~mL}$ of raw, half-ripe, and ripe ethanol extract of figs are put into two test tubes wherein tube one a buffer solution of $\mathrm{pH} 1$ is added, and in tube two a buffer solution of $\mathrm{pH} 4.5$ is added. Then the absorbance was measured using a UV-Vis spectrophotometer at a wavelength of $520 \mathrm{~nm}$ and $700 \mathrm{~nm}$.

Calculating the flavonoid levels of the ethanol extract of raw, half-ripe, and ripe figs using a differential $\mathrm{pH}$ method with absorbance values. The researcher calculated the sample in this study by using the formula from Lee et al. (2005):

Absorbansi $\mathrm{T}_{\text {Total }}=\left\{\left(\mathrm{A}_{520}-\mathrm{A}_{700}\right)_{\mathrm{pH} 1}-\left\{\left(\mathrm{A}_{520}-\mathrm{A}_{700}\right)_{\mathrm{pH}} 4.5\right\}\right.$

The flavonoid content in the sample is calculated by the formula:

$$
\text { Total Flavonoids }=\frac{\mathrm{A} \times \mathrm{Mr} \times 1000}{\varepsilon \times \mathrm{b}}
$$

where $\mathrm{A}$ is the total absorbance, is the molar absorptivity of cyanidine- 3 glucoside (26.900 $\left.\mathrm{L} / \mathrm{mol} / \mathrm{cm}^{-1}\right), B$ is the width of the cuvette $(1 \mathrm{~cm})$, $\mathrm{Mr}$ is the molecular weight of cyanidine-3-glucoside $(449.2 \mathrm{~g} / \mathrm{mol})$, and 1000 is the conversion factor from grams to milligrams.

\section{Results and Discussion}

Based on the research that has been conducted regarding the analysis of flavonoid levels in raw, half-ripe, and ripe figs, which were carried out by qualitative and quantitative tests, the results obtained are described in Table 1.

Table 1. Average levels of tin fruit flavonoids

\begin{tabular}{ccc}
\hline No. & Fruit Tins Maturity Level & Levels of Flavonoids $(\mathrm{mg} / \mathrm{L})$ \\
\hline 1 & Raw & $5.778 \times 10^{3}$ \\
2 & Half Cook & $3.056 \times 10^{3}$ \\
3 & Cook & $3.707 \times 10^{3}$ \\
\hline
\end{tabular}

The qualitative test on the extract was carried out to determine the types of compounds contained in the extract of raw, half-ripe, and ripe figs. The types of compounds to be identified are the flavonoid compound using $10 \% \mathrm{FeCl}_{3}$ solution (Minarno, 2015).

Identification of flavonoid compounds using $10 \% \mathrm{FeCl}_{3}$ solution aims to determine the presence of flavonoid compounds in the sample. The qualitative test shows that the raw, under-ripe, and ripe figs contain flavonoids which are indicated by a change in color from pink to yellow, from faded yellow to dark yellow, and from brownish orange to dark yellow (Burdock, 1996).
Based on the results of the qualitative test, there are differences in the level of color density generated in each sample. This indicates that there are differences in the number of chemical compounds in each extract which may be due to different levels of polarity and fruit maturity (Stankovic et al., 2011). Flavonoids are an important group of polyphenols. This compound is generally found in plants and is a pigment in higher plants (Singh, 2002).

Compared with the research of Refli (2012) and Hartati (2017), the results of this qualitative test show differences in the flavonoid compounds contained in the extract. This difference is thought 
to be due to differences in the variety and vegetation of the samples used, which could affect the secondary metabolite content in the sample. Red to orange color is given by flavones, dark red to brown is given by flavonols or flavonoids, green to blue is given by aglycones or glycosides.

The flavonoid compounds in figs were tested for their existence using a UV-Vis spectrophotometer, and then their levels were determined using a differential $\mathrm{pH}$ method. Basically, this differential $\mathrm{pH}$ method is used to test for the presence of total anthocyanins contained in a sample, so the anthocyanin levels obtained through this method are assumed to be the total flavonoid levels in the sample. This was done because the basic structure of the anthocyanin compound, namely $\mathrm{C}_{6}-\mathrm{C}_{3}-\mathrm{C}_{6}$, is the basic structure of the flavonoid compound.

Differential $\mathrm{pH}$ method in this study was conducted to determine the levels of flavonoids in figs. The fig extract was reacted with a buffer solution of $\mathrm{pH} 1$ and $\mathrm{pH} 4.5$ with a ratio of 3: 3 . The added buffer solution acts as a reagent. The absorbance of the fig samples in this study was measured using a UV-Vis spectrophotometer at a wavelength of $520 \mathrm{~nm}$ and $700 \mathrm{~nm}$ and was carried out three times. $\lambda=520 \mathrm{~nm}$ is $\lambda$ maximum for cyanidin-3-glucoside, and sample measurements at $\lambda=700 \mathrm{~nm}$ aim to correct or check the turbidity present in the solution analyzed (Lee et al., 2005). Flavonoid levels are determined in an acidic environment because acid is able to denature plant cell membranes and can dissolve anthocyanin pigments so that they can leave cells and can prevent flavonoid oxidation. Anthocyanins are a class of flavonoid compounds that function as natural antioxidants. In an acidic atmosphere, anthocyanins are more stable than in an alkaline or neutral atmosphere. Anthocyanins themselves are influenced by several factors, including $\mathrm{pH}$ (Aminah et al., 2016).

The results were obtained from the calculation of the concentration of flavonoids in the sample solution $(\mathrm{mg} / \mathrm{L})$, which were then converted to the concentration scale of dry weight in the sample $(\mathrm{mg} / 100 \mathrm{~g})$. Flavonoid levels in the samples of raw, half-ripe, and ripe figs were $17.334 \times 10^{3}$, $9.168 \times 10^{3}$, and $11.121 \times 10^{3} \mathrm{mg} / 100 \mathrm{~g}$, respectively. Compared with the results of previous studies, the results of this study show different results, where the levels of flavonoids obtained by Karmila (2018) were $13.4058 \times 10^{3} \mathrm{mg} / 100$ g while those obtained in this study were $17.334 \times 10^{3}$ $\mathrm{mg} / 100 \mathrm{~g}$. The results of this study indicated that the levels of flavonoids in raw figs were greater than forest onion bulbs.

The results showed that the highest levels of flavonoids were found in raw figs compared to halfripe and ripe figs. The flavonoid compounds contained in the fruit extract are the result of secondary metabolism; when the fruit is ripe, biosynthesis will occur in a different form. One of the flavonoid compounds that are often found in the fruit section, namely anthocyanidins. This compound is widely produced in raw fruit to protect the fruit from sunlight and insects. Ripe fruit contains more anthocyanins (anthocyanidin derivatives) than anthocyanidins (Crozier et al., 2006). Anthocyanins have large amounts of sugar, which are produced to attract pollinating insects. The sugar content in ripe fruit can increase the dry weight of the extract, thereby reducing the total flavonoid content to the same amount as the dry weight of the raw fruit extract. Therefore, the total flavonoid content of the raw fruit extract was higher than the ripe fruit extract in the same sample amount (Crozier et al., 2006). Flavonoids are a class of polyphenolic compounds that are known to have properties as free radical scavengers, inhibitors of hydrolysis and oxidative enzymes, and works as an anti-inflammatory (Pourmorad et al., 2006).

The results of the quantitative test of flavonoid levels, compared with previous studies' results, showed different results, where the flavonoid levels in tin leaves obtained by Refli (2012) were $11.09 \%$, and the levels of flavonoids obtained by Hartati (2017) were $13.06 \%$. Meanwhile, what was obtained in this study was $9.18 \%$. The percentage in question is the percent yield. Yield percentage is the ratio of the amount (quantity) resulting from plant extraction. These results indicate that it is true what Oliveira et al. (2010) said that the part of the fig plant that has the potential to have the highest antioxidant activity is in leaves.

\section{Conclusions}

Based on the research that has been conducted regarding the analysis of flavonoid levels in raw, half-ripe and ripe figs, it can be concluded that raw figs contain flavonoid compounds of 5.778 $\times 10^{3} \mathrm{mg} / \mathrm{L}$ equivalent to $17.334 \mathrm{mg} / 100 \mathrm{~g}$, bhalf cooked tincontaining flavonoid compounds of $3.056 \times 10^{3} \mathrm{mg} / \mathrm{L}$ equivalent to $9.168 \times 10^{3} \mathrm{mg} / 100$ $\mathrm{g}$ and bcooking tincontains flavonoid compounds of $3.707 \times 10^{3} \mathrm{mg} / \mathrm{L}$ equivalent to $11.121 \times 10^{3}$ $\mathrm{mg} / 100 \mathrm{~g}$.

\section{Acknowledgments}

The authors would like to thank the laboratory assistant for the Chemistry Laboratory of the Teaching and Education Faculty, Tadulako University a lot to help the authors in completing this research.

\section{Reference}

Aminah., Tomayahu, N., \& Abidin, Z. (2016). Penetapan kadar flavonoid total ekstrak etanol kulit buah alpukat (Persea americana mill.) dengan metode spektrofotometri UV-Vis. Jurnal Fitofarmaka Indonesia, 4(2), 226-230.

Aytekin, O., \& Caliskan, O. (2008). Fruit characteristics of table fig (Ficus carica) cultivars in subtropical climate conditions of the 
mediterranean region. New Zealand Journal of Crop and Horticultural Science, 36(2), 107-115.

Crisosto, H C., Bremer, V., Ferguson, L., \& Crisosto, G. (2010). Evaluating quality attributes of four fresh fig (Ficus carica L.) cultivars harvested at two maturity stages. Horticultural Science, 45(4), 707-710.

Crozier, A., Jaganath, I. B., \& Clifford, M. N. (2006). Phenols, polyphenols and tannins: An overview. In A. Crozier, M. N. Clifford, H. Ashihara (Eds.), Plant secondary metabolites: occurrence, structure and role in the human diet (pp 1-22). Amerika Serikat: Blackwell Publishing Ltd.

Ghazi, F., Rahmat, A., Yassin, Z., Ramli, N. S., \& Buslima, N. A. (2012). Determination of total polyphenols and nutritional composition of two different types of ficus carica leaves cultivated in Saudi Arabia. Pakistan Journal of Nutrition, 11(11), 1061-1065.

Gupta, N., \& Shaw, J. D. (2015). Employee compensation: the neglected area of HRM research. Human Resource Management Review, 24(1), 1-4.

Gustandy, M., \& Soegihardjo, C. J (2016), Uji aktivitas antioksidan menggunakan radikal 1 , 1-difenil-2-pikrihidrazil dan penetapan kandungan fenolik total fraksi etil asetat ekstrak etanol buah anggur bali (Vitis vinifera L.), Jurnal Farmasi Sains dan Komunitas, 10(2), 109-120.

Burdock, G. A. (1996). Encyclopedia of food and color additives. Boca Raton: CRC Press.

Harborne, J. B. (1984). Phytochemical methods: A guide to modern techniques and plant analysis. New York: Chapman and Hall.

Hartati, R. U. A. (2017). Uji antiinflamasi ekstrak etanol daun tin (ficus carica L.) pada tikus jantan galur wistar yang diinduksi karagenin. Skripis Tidak Diterbitkan. Surakarta: Universitas Muhamadiyah.

Joseph, B., \& Raj, S. J. (2011). Pharmacognostic and phytochemical properties of Ficus carica Linn - An overview. International Journal of PharmTech Research, 3(1), 8-12.

Karmila., Jura. M. R., \& Tiwow, V. M. (2018). Penentuan kadar flavonoid dan vitamin C dalam umbi bawang hutan (eleutherine bulbosa (mill) urb) yang berasal dari desa matantimali kabupaten sigi. Jurnal Akademika Kimia, 7(2), 66-69.

Lee, J., Durst, R. W., \& Wrolstad, R. E. (2005). Determination of total monomeric anthocyanin pigment content of fruit juices, beverages, natural colorants, and wines by the $\mathrm{pH}$ differential method: collaborative study. Journal of Association of Official Agricultural Chemists International, 88(5), 1269-1278.

Minarno, E. B. (2015). Skrining fitokimia dan kandungan total flavanoid pada buah carica pubescens lenne $\& \mathrm{k}$. koch di kawasan Bromo, Cangar, dan dataran tinggi Dieng. El-Hayah: Jurnal Biologi, 5(2), 73-82

Oliveira, A. P., Silva, L. R., Andrade, P. B., Valentao, P., Silva, B. M., Pereira, J. A., \& de Pinho, P. G. (2010). Determination of low molecular weight volatiles in Ficus carica using HS-SPME and GC/FID. Food Chemistry, 121(4), 1289-1295.

Pourmorad, F., Hosseinimehr, S. J., \& Shahabimajd, N. (2006). Antioxidant activity, phenol. and flavonoid contents of some selected Iranian medicinal plants. African Journal of Biotechnology, 5(11), 1142-1145.

Refli, R. (2012). Potensi ekstrak daun tin (Ficus carica L.) sebagai antioksidan dan aktivitas hambatannya terhadap proliferasi sel kanker hela. Jurnal Bogor Agriciltural University, 1(2), 1-9.

Rezki, A. P., Gonggo, S. T., \& Sabang, S. M. (2017). Analisis kadar flavonoid dan fenolat pada kulit buah manggis (Gracinia mangostana. L). Jurnal Akademika Kimia, 6(4), 196-199.

Singh, N. (2003). Analyzing cultural sensitivity of websites. Journal of Practical Global Business, 1(2), 32-53.

Sobir, \& Amalya, M. (2011). 20 buah koleksi ekslusif. Jakarta: Penebar Swadaya.

Stankovic, M. S., Niciforovic, N., Topuzovic, M., \& Solujic, S. (2011). Total phenolic content, flavonoid concentrations and antioxidant activity, of the whole plant and plant parts extracts from Teuchium montanum L. var. montanum, F. supinum (L.) Reichenb [catatan penelitian]. Biotechnology and Biotechnological Equipment, 25(1), 2222-2227. 